$5-25-2019$

\title{
Sea-level driven land conversion and the formation of ghost forests
}

Matthew L. Kirwan

Virginia Institute of Marine Science

Keryn B. Gedan

Follow this and additional works at: https://scholarworks.wm.edu/vimsarticles

Part of the Earth Sciences Commons, and the Environmental Sciences Commons

\section{Recommended Citation}

Kirwan, Matthew L. and Gedan, Keryn B., "Sea-level driven land conversion and the formation of ghost forests" (2019). VIMS Articles. 1466.

https://scholarworks.wm.edu/vimsarticles/1466

This Article is brought to you for free and open access by the Virginia Institute of Marine Science at W\&M ScholarWorks. It has been accepted for inclusion in VIMS Articles by an authorized administrator of W\&M ScholarWorks. For more information, please contact scholarworks@wm.edu. 


\section{Sea-level driven land conversion and the formation of ghost forests Matthew L. Kirwan ${ }^{1}$ and Keryn B. Gedan ${ }^{2}$ \\ ${ }^{1}$ Virginia Institute of Marine Science, College of William and Mary, Gloucester Point, VA 23062 \\ ${ }^{2}$ George Washington University, Washington, D.C. 20052}

Ghost forests created by the submergence of low-lying land are one of the most striking indicators of climate change along the Atlantic coast of North America. Although dead trees at the margin of estuaries were described as early as 1910, recent research has led to new recognition that the submergence of terrestrial land is geographically widespread, ecologically and economically important, and globally relevant to the survival of coastal wetlands in the face of rapid sea level rise. This emerging understanding has in turn generated widespread interest in the physical and ecological mechanisms influencing the extent and pace of upland to wetland conversion. Choices between defending the coast from sea level rise and facilitating ecosystem transgression will play a fundamental role in determining the fate and function of low-lying coastal land.

Sea level rise rates have been accelerating since the end of the $19^{\text {th }}$ century, impacting low elevation land along coasts and estuaries around the world ${ }^{1}$. Sea level rise enhances flooding and saltwater intrusion, and threatens coastal communities, infrastructure, and ecosystems ${ }^{2-4}$. Ghost forests and abandoned farmland are striking indicators of sea-level driven land conversion. Dead trees and stumps surrounded by marshland, for example, represent relic forestland that has been replaced by intertidal vegetation. Similarly, bare soil and wetland plants at the edges of agricultural fields indicate the encroachment of wetlands into formerly productive farmland. These visual illustrations of land conversion are common along the North American Atlantic and Gulf of Mexico coasts, and reflect rapid ecosystem change and the inland migration of the intertidal zone in response to sea level rise (Fig. 1).

The ongoing conversion of uplands to wetlands is both economically and ecologically important. Eustatic sea level rise is predicted to rise between $0.4-1.2 \mathrm{~m}$ by $2100^{5}$. More than 600 million people live in lowlying coastal areas $(<10 \mathrm{~m} \text { elevation })^{3}$, and approximately 50 million people live on land predicted to be permanently inundated with $0.5 \mathrm{~m}$ of sea level rise ${ }^{6}$. In the conterminous United States alone, $1 \mathrm{~m}$ of relative sea level rise would convert approximately $12,000-49,000 \mathrm{~km}^{2}$ of dry land to intertidal land without flood-defense structures ${ }^{7,8}$. Heavily populated, low-lying regions including subsiding deltas and island nations will be most affected ${ }^{6}$. In Egypt and Bangladesh, sea level rise could cause a 15-19\% loss in habitable land and displace $13-16 \%$ of the population ${ }^{9}$. In the United States, residential property values 
may decrease with proximity to wetlands ${ }^{10}$, and the conversion of uplands to wetlands is perceived as

36 highly undesirable by many landowners ${ }^{11}$. On the other hand, the marshes and mangroves that replace

37 inundated forests and farmland are considered among the most valuable ecosystems in the world

38 because they improve water quality, reduce coastal erosion, protect against flooding, sequester carbon,

39 and support marine fisheries ${ }^{12}$. Therefore, coastal sustainability in the face of sea level rise involves

40 rapidly moving ecosystem boundaries and complex tradeoffs between the direct and indirect values of

41 different land uses ${ }^{13}$.

42

43 Although ghost forests first appeared in the scientific literature over a century ago ${ }^{14}$ and are a

44 prominent feature of many coastal and estuarine landscapes from the Atlantic Coast of Canada to the

45 Gulf Coast of the United States ${ }^{15-22}$, coastal change research has traditionally focused on more seaward

46 environments, such as barrier islands, intertidal wetlands, and subtidal ecosystems ${ }^{23,24}$. Extensive

47 research into those portions of the coastal landscape has identified a number of feedbacks between

48 flooding, vegetation growth, and sediment transport that allows them to resist sea level rise until some

49 threshold rate is exceeded. For example, marshes, mangroves, and oyster reefs are well known to resist

50 sea level rise by accumulating sediment and growing vertically ${ }^{24-26}$. Although more work is needed to

51 determine if analogous processes allow terrestrial land to resist sea level rise, observations of

52 widespread land conversion ${ }^{16,17,19}$ suggest terrestrial ecosystems largely lack mechanisms to engineer

53 vertical soil growth. Therefore, forests and other terrestrial ecosystems are potentially more sensitive to

54 sea level rise than better studied intertidal and subtidal portions of the coastal landscape ${ }^{20}$.

56 Here, we review the natural and human mediated processes that influence sea-level driven land

57 conversion. Although the review considers a variety of land types, we emphasize the conversion of

58 forests to marshes because it is the most common and well-studied conversion, and because it produces

59 ghost forests that are a striking visual indicator of sea-level driven land conversion. The first section

60 illustrates that historical land submergence is geographically widespread, and has impacted terrestrial

61 forests, agricultural fields, and developed landscapes alike. The second section discusses the ecological

62 processes linking sea level rise and land conversion, such as plant population demography and

63 community reorganization that shape the environmental consequences of land conversion. The third

64 section argues that drowning of uplands is potentially the most important process determining future

65 wetland area, and the fourth section considers the extent to which humans will prevent or facilitate

66 coastal land submergence. The review ends with implications for land management, and highlights 
uncertainty in local flood defense strategy as the key knowledge gap limiting our ability to predict future

68 sea-level driven land conversion and its impact on coastal ecosystems.

\section{Extent and physical controls of historical land submergence}

71 Ghost forests, abandoned agricultural fields, and other indicators of historical land submergence occur

72 throughout low-lying and gently sloping portions of the Atlantic and Gulf coasts of North America ${ }^{15-20}$

73 (Fig. 1). Land submergence is most extensive within the mid-Atlantic sea-level rise hotspot that stretches

74 from North Carolina to Massachusetts, where relative sea level is rising three times faster than eustatic

75 rates $^{27}$. For example, $400 \mathrm{~km}^{2}$ of uplands in the Chesapeake Bay region have converted to tidal marsh

76 since the mid-1800s ${ }^{19}$, and large tracts of hardwood and cedar forest death have been observed in

77 Delaware Bay ${ }^{16}$. However, ghost forests are not confined to the sea level rise hotspot. Ghost forests

78 have also been documented throughout the Florida Gulf Coast ${ }^{17,18}$, the St. Lawrence estuary of Canada ${ }^{15}$,

79 and tidal freshwater forests in South Carolina, Georgia, and Louisiana ${ }^{21,28}$. There has been $148 \mathrm{~km}^{2}$ of

80 forest conversion over 120 years along the Florida Gulf Coast ${ }^{17}$, and near complete loss of pine forests in

81 the Lower Florida Keys ${ }^{29}$. Surprisingly, the phenomenon has not been widely documented on coastal

82 plains outside of the United States. There are no reports of ghost forests from low-lying tropical regions

83 where the phenomenon would be predicted, such as the Yucatan Peninsula, Mexico ${ }^{30}$, or from the

84 Pacific Ocean's western margin, such as along eastern China, due to the prevalence of seawalls there ${ }^{31}$.

Observations of historical land submergence indicate that topography and relative sea level rise are the

87 two most important controls on the rate of lateral forest retreat ${ }^{32}$. Migration rates are substantially

88 lower in U.S. Pacific Coast and New England estuaries $\left(<10 \mathrm{~cm} \mathrm{yr}^{-1}\right)^{33,34}$ than in the mid-Atlantic coastal

89 plain (up to $7 \mathrm{~m} \mathrm{yr}^{-1}$ ) $16,19,35$ where rates of land conversion are inversely correlated with slope ${ }^{16,19}$.

90 Although mortality of canopy trees may depend on punctuated disturbance events such as storms and

91 therefore lag behind sea level rise ${ }^{30,36}$, land conversion is tightly tied to sea level over decadal

92 timescales ${ }^{16,18,30}$. For example, the elevation of coastal treelines has increased in parallel with late-

93 Holocene sea level rise, and lateral rates of forest retreat are 2-14 times higher than pre-industrial

94 rates $^{20,35}$ (Fig. 2).

96 The conversion of agricultural fields and residential lawns to wetlands is less visually striking than ghost

97 forests, as one herbaceous plant community is replaced by another, but is much more economically 
to mowed lawns ${ }^{37}$. Abandonment of agricultural land due to salinization is prevalent in low elevation coastal regions around the world, including large areas of North Carolina ${ }^{38,39}$, Italy ${ }^{40}$, Mexico ${ }^{41}$, and

101 Bangladesh ${ }^{42}$. In Bangladesh, saltwater intrusion has salinized 10,000 km² of land in the last 4 decades,

102 including an estimated $3,000 \mathrm{~km}^{2}$ of arable land ${ }^{42}$. Bangladeshi farmers responded by increasing

103 fertilizer applications to compensate for losses in yields, switching crops, and converting 1,380 $\mathrm{km}^{2}$ of

104 farmland to shrimp ponds ${ }^{42}$. Sea level rise is forecasted to result in major losses in agricultural area over

105 the next century in nations with agricultural production in deltaic or coastal regions (e.g. 1,000 km² will 106 be lost within the Pearl River Delta region of China) ${ }^{43}$. The Mekong Delta of Vietnam stands to be one of 107 the most affected areas in the world, where losses in rice production threaten global food supply ${ }^{44}$

\section{Ecological processes linking sea level and land conversion}

110 Dead trees underlain by wetland vegetation are a striking final indicator of uplands that have been 111 displaced by sea level rise and saltwater intrusion (Fig. 3). However, the creation of ghost forests and 112 the wholesale reorganization of ecosystems begins with more subtle changes that can be anticipated 113 with a deeper understanding of the ecological processes that link sea level rise and land conversion. In 114 the early stages of groundwater salinization, live trees may exhibit reduced sap flow ${ }^{45}$ and annual 115 growth ${ }^{46,47}$ though reduced growth is not always observed ${ }^{34,48}$. During the next phase of ghost forest 116 formation, forest distress becomes more visible. Young trees die conspicuously and tree recruitment 117 ceases $^{30,46}$ (Fig. 3a). Because recruitment ceases prior to the death of mature trees ${ }^{30,46,48}$, tree age 118 distributions skew towards older trees at lower elevations ${ }^{36,46}$, and relict trees stand as ghost forests in 119 waiting ${ }^{18}$. Salt tolerant species establish in the understory as adult trees die $^{30}$, aided by increased light 120 penetration and seed delivery from storm wrack deposits ${ }^{49}$. Shrubs often dominate the transition from 121 forest to tidal wetland ${ }^{18,21,50}$ (Fig. 3b). Of the $148 \mathrm{~km}^{2}$ of converted forest land in Big Bend, Florida, 55\% 122 converted to marsh, while $45 \%$ converted to a shrub-dominated habitat ${ }^{17}$ that persisted for 20 years ${ }^{18}$.

123 These areas may be particularly persistent in formerly agricultural areas, where land is graded flat during 124 cultivation. Finally, dead tree trunks and stumps persist in tidal marshes for decades, a lasting remnant 125 of the forests displaced by sea level rise and saltwater intrusion (Fig. 3c).

127 Upland ecosystem mortality is driven by the synergistic impacts of salinity and inundation, which are 128 more challenging for plants than either stress alone ${ }^{21,51-53}$. Generally, plants that tolerate flooding are 129 more resistant to low level salinity stress ${ }^{21}$. Variation in stress tolerances between plant species can 130 explain differences in the rate of transition of different forest types. For example, in Delaware Bay, 
131 Atlantic white cedar (Chamaecyparis thyoides) forests died back at faster rates than hardwood forests

132 (typical species: red maple [Acer rubrum], sweetgum [Liquidambar styraciflua], blackgum [Nyssa

133 sy/vatica]). Eastern redcedar (Juniperus virginiana) is among the most tolerant tree species; the species

134 outlasted loblolly pine (Pinus taeda), winged elm (Ulmus alata), and Florida maple (Acer floridanum)

135 during forest dieback in Florida ${ }^{54}$. Trees and crops are most vulnerable to salinity stress during

136 germination and as seedlings ${ }^{51,55,56}$. Mortality of relatively salt-tolerant tree seedlings occurs when

137 salinity exceeds about $5 \mathrm{ppt}^{57}$, and most crops cannot tolerate sustained salinities over $2 \mathrm{ppt}^{58,59}$.

139 The transition of uplands to wetlands can be either gradual or punctuated by disturbance events such as

140 hurricanes, fires, and insect outbreaks. Pulses of high salinity water during storms often trigger

141 mortality ${ }^{60,61}$. Although storm waters recede in hours, salinity effects can linger for years to decades in

142 the groundwater ${ }^{62,63}$, and individual storms have lasting impacts on tree growth ${ }^{47}$. Storm floods can

143 reach tens of kilometers inland and are accompanied by wind, erosion, and wrack disturbances.

144 Correspondingly, shifts in upland land cover occur suddenly, when storm-related disturbance destroys

145 an upland ecosystem ${ }^{61}$. In the absence of major disturbance, change may occur more gradually, as

146 elevated groundwater salinities slowly take their toll on a plant community that is intolerant to salinity.

147 Moreover, the impact of storms increases with sea level rise, leading to the progressive inland retreat of

148 upland ecosystems through time ${ }^{15}$. Terrestrial water budgets can also affect the rate of change, as

149 saltwater intrusion resulting from sea level rise is exacerbated by drought ${ }^{54}$, surface and groundwater

150 withdrawals ${ }^{41}$, and hydrological connectivity from dams, ditching, and canals ${ }^{64}$.

152 Ecosystem transitions affect the provision of ecosystem services, though the exact nature of these shifts

153 varies based on tradeoffs in services between upland and wetland ecosystems ${ }^{13,65}$. Tidal wetlands

154 exhibit much higher areal rates of carbon sequestration and storage than terrestrial environments ${ }^{7}$.

155 Therefore, the conversion of forests and croplands to tidal wetlands will increase total carbon

156 sequestration of a region, provided that gains are not offset by concurrent losses in tidal wetland area

157 (next section). Similarly, upland conversion of agricultural lands, a nutrient source to adjacent

158 waterways and estuaries ${ }^{66}$, to tidal wetlands, a nutrient $\operatorname{sink}{ }^{12}$, should ultimately increase nutrient

159 uptake. During transition, however, salinization of uplands can result in short-lived ${ }^{21}$ releases of massive

160 amounts of legacy nutrients that have accumulated in cultivated soils over prior decades. In North

161 Carolina, saltwater intrusion into former farmland is predicted to release $18 \times 10^{6} \mathrm{~kg}$ ammonium, or

162 approximately half the annual ammonium flux of the Mississippi River to the Gulf of Mexico ${ }^{39}$. In 
163 Maryland, high releases of phosphate occur during saltwater intrusion into agricultural land ${ }^{67}$. These

164 nutrient releases contribute to coastal eutrophication and associated algal blooms and dead zones ${ }^{68}$.

Upland conversion may reduce biodiversity provisioning, as wetland migration represents an

167 opportunity for invasive species expansion. In Delaware Bay, 30\% of converted forest area became

168 native tidal marsh habitat, while 60\% became dominated by the invasive common reed (Phragmites

169 australis) ${ }^{16}$. The conversion of uplands to the invasive common reed during ghost forest formation is of

170 particular concern for Atlantic tidal marsh endemic species with narrow habitat requirements, such as

171 the diamondback terrapin (Malaclemys terrapin) ${ }^{69}$ and the saltmarsh sparrow (Ammodramus

172 caudacutus) predicted to go extinct by 2030 due to sea level rise ${ }^{70}$. In Florida, the invasive Brazilian

173 pepper (Schinus terebinthifolius) inhabits a similar niche to the common reed in that it outcompetes

174 native species in the ecotone and exhibits wide salinity tolerance, and is also expected to spread during

175 upland conversion ${ }^{18,71}$. Thus, sea-level driven land conversion will effect both the composition and

176 function of the coastal landscape.

\section{Implications for the survival of adjacent wetlands}

179 The conversion of uplands to wetlands is a primary mechanism for wetland survival in the face of sea

180 level rise, and counterintuitively leads to predictions that wetlands may expand with sea level rise under

181 certain conditions ${ }^{2,8,17}$. At the most basic level, wetlands must migrate to higher elevations faster than

182 they erode laterally and drown vertically in order to maintain their size ${ }^{32}$. Although marshes and

183 mangroves build soil vertically, there are limits to the rate of sea level rise that wetlands can survive in

184 place. Numerical models predict that maximum possible vertical accretion rates overlap with the range

185 of predicted sea level rise rates for 2100 (generally $5-30 \mathrm{~mm} / \mathrm{yr}$ ) ${ }^{72}$, and observations of wetland

186 drowning indicate that these limits have already been exceeded in some places ${ }^{73,74}$. When these

187 threshold rates of sea level rise are exceeded, wetlands must migrate laterally into submerging uplands

188 to survive.

190 Historical observations and simple analyses of coastal topography indicate that upland drowning has the 191 potential to create large areas of new wetlands that are comparable in size to existing wetlands. For 192 example, historical maps of the Chesapeake Bay suggest that approximately $1 / 3$ of all marshland today 193 formed as a result of migration into drowning uplands since the mid-19 ${ }^{\text {th }}$ Century, and that upland 194 drowning compensated for historical erosion of marshes in the region ${ }^{19}$. On the Florida Gulf Coast, 
195 marsh formation in submerging uplands has outpaced historical loss, and led to net marsh expansion ${ }^{17}$

196 More work is needed to infer how future sea level rise will alter the timescales associated with wetland 197 loss and migration, but these historical trends together with observations of ghost forests underlain by 198 marsh vegetation, suggest that wetland migration can occur on the decadal-century timescales relevant 199 to wetland loss. Across the conterminous United States, there are $\sim 26,000 \mathrm{~km}^{2}$ of saline wetlands ${ }^{75}$, and 200 sea level rise of $1.2 \mathrm{~m}$ would inundate $\sim 12,000-49,000 \mathrm{~km}^{2}$ of uplands ${ }^{7}$. Thus, the formation of new

201 wetlands in drowning uplands has the potential to compensate for even large losses of existing

202 wetlands.

Rates of marsh migration generally increase in parallel with sea level rise ${ }^{20,35,37}$, but existing marsh is 205 relatively resistant to sea level rise because enhanced flooding leads to faster vertical accretion ${ }^{76}$. 206 Upland migration, therefore, allows marshes to potentially expand, rather than contract, in response to 207 sea level rise ${ }^{13,76}$. Numerical modeling suggests that marshes adjacent to gently sloping uplands will 208 expand under moderate increases in sea level rise, followed by inevitable contraction when high rates of 209 sea level rise lead to widespread drowning of existing marshland ${ }^{76}$. The particular rate of sea level rise 210 that leads to a transition from marsh expansion to marsh contraction depends principally on the slope of 211 adjacent uplands ${ }^{32}$, anthropogenic barriers to migration ${ }^{77}$, and factors such as tidal range and sediment 212 supply that control the resistance of existing marsh to sea level rise and edge erosion ${ }^{24}$. Nevertheless, 213 numerical models that consider both dynamic marsh accretion and the potential for marshes to migrate 214 inland suggest that many marshes will expand under moderate rates of sea level rise, and then contract 215 under higher rates $^{13,76,78,79}$ (Fig. 4).

217 These types of simple landscape models based on topography and land use have thus far assumed a 218 binary response of land types to sea level rise (e.g. complete conversion of inundated forestland and no 219 conversion of inundated urban land, next section), and that wetlands will migrate into uplands as soon 220 as they become sufficiently inundated (e.g. without ecological lags, previous section). Other work 221 identifies additional caveats. For example, the response of low-lying land to sea level rise will vary both 222 within and across regions ${ }^{19,80-82}$, where regions with steep upland topography and anthropogenic 223 barriers to migration may see near complete loss of marshes ${ }^{81}$. In places where marshes persist, the 224 proportion of flood-tolerant vegetation types will increase ${ }^{78,79,81}$ and newly created wetlands may 225 themselves be vulnerable to sea level rise ${ }^{10}$. Salt water intrusion into freshwater soils increases organic 226 matter decomposition rates so that soil elevation loss could limit wetland migration and/or survival in 
227 submerging forests with organic rich soils ${ }^{4,28}$. Finally, interactions between multiple facets of climate

228 change and socioeconomic factors (e.g. changing hurricane frequencies and flood protection strategies)

229 may influence sea-level driven land conversion in unanticipated ways. Nevertheless, recent global

230 modeling suggests wetland migration into submerging uplands is the single biggest factor influencing

231 wetland area through time, and that global wetland area could increase by up to $60 \%$ by 2100 for a 1.1

232 m sea level rise (Fig. 5).

234 Opportunities and barriers to coastal land submergence

235 Although there is abundant land that could be inundated by sea level rise, anthropogenic structures and 236 coastal development may prevent land conversion in many regions of the world. Ghost forests, 237 abandoned farmland, and other indicators of land submergence are most common in the Southeastern 238 and mid-Atlantic United States, in part because these coastal regions are largely rural and devoid of 239 large, systematic flood control structures outside of major cities. In contrast, ghost forests are rare in 240 Western Europe and China because extensive seawalls and dykes protect uplands from sea level rise and 241 coastal flooding ${ }^{31,84}$. Large flood control structures are less common in the United States, but migration

242 of wetlands into submerging uplands may instead be prevented by local barriers including berms,

243 bulkheads, roads, ditches with floodgates, and impervious surfaces ${ }^{80,85}$. For example, $42 \%$ of all land less

244 than $1 \mathrm{~m}$ above spring high water is currently developed along the U.S. Atlantic coast, whereas less than

$24510 \%$ is currently protected against development ${ }^{86}$.

247 Human impacts are typically perceived as barriers to wetland migration, but people also facilitate sea248 level driven land conversion, and the net-impact can be difficult to discern. Historical marsh migration 249 rates likely decrease with the degree of coastal development in the Chesapeake Bay region, but the 250 relationship is weak and highly site specific ${ }^{19,85}$. Elsewhere, suburban lawns convert to marsh as quickly 251 as adjacent forests ${ }^{37}$, and reclaimed agricultural areas are particularly susceptible to salinization and 252 land conversion ${ }^{40}$. Wetland restoration projects commonly remove berms to reconnect agricultural 253 fields and other land types with tidal flooding ${ }^{87,88}$. Barrier removal has mixed effects. Since barriers

254 enhance land subsidence and limit sedimentation, the land behind the barriers may require substantial 255 restoration to be suitable for wetlands ${ }^{87-90}$. Indeed, accidental or poorly planned breaches after 256 significant subsidence can rapidly drown wetlands ${ }^{89}$. In other cases, large levees are carefully removed 257 or moved further inland to create wetlands that contribute to natural flood protection in a concept 258 known as nature-based engineering or managed realignment ${ }^{84,90}$ (Fig. 5a). Finally, human actions 
sometimes unintentionally accelerate land submergence by increasing rates of saltwater intrusion via 260 groundwater withdrawal and/or subsidence ${ }^{4,91}$ or building canals that input saltwater ${ }^{64}$. Nevertheless, 261 anthropogenic barriers block substantial wetland migration today in many regions ${ }^{80,81}$, and wholesale

262 submergence and abandonment of low-lying coastal land is unlikely because in most cases the cost of 263 conventional flood control structures is far less than the cost of economic damages associated with

264 flooding ${ }^{92}$.

The United States Gulf Coast represents an interesting case study for how population growth and floodcontrol structures might interact to determine the extent of upland land conversion (Fig. 6a). This region contains approximately $50 \%$ of U.S. saline wetlands ${ }^{75}$, high variability in human population densities and rates of relative sea level rise, and the most extensive flood protection system in the United States ${ }^{77,82,93}$. Analysis of topography and land use across the entire U.S. Gulf Coast indicate that $39,000 \mathrm{~km}^{2}$ of land is

271 vulnerable to submergence under a $1.2 \mathrm{~m}$ sea level rise, and that barriers projected under population

272 growth will prevent conversion in an additional $6,000 \mathrm{~km}^{277}$. This work highlights that there are strong

273 spatial gradients in both opportunities and barriers to migration within the Gulf Coast region, such that 274 the absence of land conversion in highly urbanized areas may result in large reductions in local wetland 275 area ${ }^{77,82}$. Nevertheless, these analyses have three fundamental implications at the regional scale. First, 276 current and projected barriers to wetland migration are small relative to the total amount of land 277 available for migration ( 15\%), such that the total area of land that will be inundated will be large 278 regardless of protection of urban areas. Second, only $35 \%$ of land available for migration is currently owned by government and private conservation organizations ${ }^{77}$, suggesting that most land conversion will take place on private land and depend on local decisions not fully considered in analyses based on urbanization and levee construction. Finally, the area of land potentially available for saline wetland

282 migration $\left(39,000 \mathrm{~km}^{2}\right)^{77}$ is nearly three times the area of land currently occupied by saline wetlands on 283 the Gulf Coast $\left(13,600 \mathrm{~km}^{2}\right)^{75}$ and larger than the current extent of saline wetlands in the entire conterminous United States $\left(26,000 \mathrm{~km}^{2}\right)$. Together, these observations emphasize that sea-level driven

285 land conversion will be widespread and a fundamental determinant of wetland area at regional scales, 286 even in the presence of urban barriers. coastal flooding depends not only on the rate of sea level rise, but also on a variety of human decisions 290 influenced by complex socio-economic factors. There are strong landowner attitudes against wetland 
291 migration ${ }^{11}$ (Fig. 6b), growing coastal populations ${ }^{94}$, and it is economically rational to build flood defense

292 structures for most of the world's coasts ${ }^{92}$. On the other hand, rising sea level and energy costs suggest

293 that building and maintenance costs will increase through time, such that conventional engineering may

294 be unsustainable in the long term ${ }^{95,96}$. Rising costs may especially prevent engineering solutions in

295 developing countries and poorer regions ${ }^{3}$. Interestingly, highly developed deltaic regions, including the

296 Mississippi, Rhone, and East Asian deltas, are the most vulnerable to rising energy costs ${ }^{96}$. Therefore,

297 regions with large areas of currently protected land are also the most likely to incorporate nature-based

298 engineering approaches that would allow submergence of some land for the first time in centuries ${ }^{84,90 .}$

While the factors that contribute to flood defense are ultimately quite complex, levees generally occur where population densities in the 100 year coastal flood plain exceed 20 people per $\mathrm{km}^{2}$, and global modeling suggests this threshold represents a key determinant of wetland fate under sea level rise and population growth ${ }^{83}$. Lower population thresholds, reflecting nature based engineering, lead to wetland expansion, whereas higher thresholds, reflecting conventional engineering, lead to wetland contraction (Fig. 5b). Therefore, decisions to defend or abandon portions of the coast represent a fundamental, if not primary, determinant of coastal submergence and the migration of wetlands into uplands ${ }^{24,83}$.

\section{Recommendations for future research}

309 Our review suggests that widespread sea-level driven submergence of low-lying land will continue in the

310 future, even under scenarios of coastal population growth and large-scale defense of urban areas.

311 However, land conversion will largely take place on privately owned land ${ }^{82,86}$, where landowner

312 attitudes and adaptation efforts suggest local resistance ${ }^{70}$. We therefore pose the following 3 questions

313 to guide future research and land management decisions:

315 1. Is land conversion inevitable on privately owned, rural land? Research in the last 5 years has identified 316 and mapped large barriers to wetland migration such as urban land and publically owned levees at 317 regional scales ${ }^{77,80-82}$. However, the majority of vulnerable land is located on private property in rural 318 areas $^{38,82,87}$. Future research should investigate the efficacy of local and privately maintained barriers 319 such as berms, ditches, and secondary roads, and the probability and consequences of barrier failure. 320 Barriers influence the adaptive capacity of coastal systems by enhancing land subsidence and limiting 321 sedimentation. Therefore, this research should quantify key thresholds in the timing of barrier $322 \mathrm{removal} /$ failure that minimize both the cost of abandoned land and the cost of restoration. Government 
323 and conservation organizations are increasingly preserving wetland "migration corridors," but

324 understanding of if and how landowners influence land submergence will help prioritize conservation 325 efforts.

327 2. Can transitional land uses and nature-based engineering compensate for tradeoffs between private 328 property and ecosystem service values? Sea-level driven land conversion leads to simultaneous loss in 329 value for private landowners and gain in ecosystem services for the general public ${ }^{19,97}$. Future research 330 should focus on whether transitional land and water management decisions, such as planting salt331 tolerant crops $^{98}$, leasing land to hunt clubs, early harvest of susceptible timber lands, and groundwater

332 manipulations ${ }^{4}$ could significantly offset economic losses and influence the function of newly forming

333 wetlands. Future research should also consider the viability of nature-based engineering, where limited 334 wetland migration could simultaneously enhance natural flood protection and reduce levee 335 maintenance costs ${ }^{84,97}$.

337 3. How can policy incentives shape the future of coastal upland conversion? Programs in the United 338 States that provide assistance or recommendations to landowners affected by sea level rise are few and 339 harshly criticized for providing perverse subsidies ${ }^{99}$ and benefiting repeatedly flood damaged and 340 reconstructed properties ${ }^{100}$. Programs such as the USDA's Conservation Reserve Program, that subsidize 341 remediating salinity damage on farm fields, could be repurposed as instruments for adaptation to sea

342 level rise. Regional predictions for tidal wetland habitat gain or loss should set the context for 343 management and policy incentives to either prioritize wetland migration or upland protection ${ }^{100}$.

345 In summary, our review highlights extensive sea-level driven land conversion, marked by ghost forests

346 and abandoned agricultural land that represent relict features of a rapidly submerging coast.

347 Accelerated sea level rise over the next 80 years could potentially create new wetlands equivalent in size 348 to current wetlands, even under scenarios of coastal population growth and urban levee construction. 349 These changes will happen disproportionately on rural and private lands where efforts to prevent or 350 promote land conversion are poorly understood. Given the extent of historical change, the magnitude of 351 forecasted change, and an unpredictable human response, sea-level driven land submergence is likely to 352 lead to wholesale reorganization of coastal ecosystems and economies within this century. 


\section{References}

1. Kemp, A. C. et al. Climate related sea-level variations over the past two millennia. Proc. Natl Acad. Sci. USA 108, 11017-11022 (2011).

2. Hopkinson, C. S., Lugo, A. E., Alber, M., Covich, A. P. \& Van Bloem, S. J. Forecasting effects of sealevel rise and windstorms on coastal and inland ecosystems. Front Ecol Environ 6, 255-263 (2008).

3. Neumann, B., Vafedis, A. T., Zimmermann, J. \& Nicholls, R. J. Future coastal population growth and exposure to sea-level rise and coastal flooding-a global assessment. PLOS ONE 10, e0118571.i (2015).

4. White, E. \& Kaplan, D. Restore or retreat? Saltwater intrusion and water management in coastal wetlands. Ecosyst. Health Sustainability 3, e01258 (2017).

5. Horton, B. P., Rahmstorf, S., Engelhart, S. E. \& Kemp, A. C. Expert assessment of sea-level rise by AD 2100 and AD 2300. Quat. Sci. Rev. 84, 1-6 (2014).

6. Rasmussen, D. J. et al. Extreme sea level implications of $1.5^{\circ} \mathrm{C}, 2.0^{\circ} \mathrm{C}$, and $2.5^{\circ} \mathrm{C}$ temperature stabilization targets in the 21st and 22nd centuries. Environ. Res. Lett. 13, 034040 (2018).

7. Morris, J. T., Edwards, J., Crooks, S. \& Reyes, E. Assessment of carbon sequestration potential in coastal wetlands. In Recarbonization of the biosphere: Ecosystems and the Global Carbon Cycle (eds Lal, R. et al.). 517-531 (Springer, Dodrecht, 2012).

8. Haer, T., Kalnay, E., Kearney, M. \& Moll, H. Relative sea-level rise and the conterminous United States: Consequences of potential land inundation in terms of population at risk and GDP loss. Glob. Environ. Chang. 23, 1627-1636 (2013).

9. Milliman, J. D., Broadus, J. M. \& Gable, F. Environmental and economic implications of rising sea level and subsiding deltas: the Nile and Bengal examples. Ambio. 18, 340-345 (1989).

10. Bin, O. and Polasky, S. Evidence on the amenity value of wetlands in a rural setting. Am. J. Agric. Econ. 37, 589-602 (2005).

11. Field, C. R., Dayer, A. A. \& Elphick, C.S. Social factors can influence ecosystem migration. Proc. Natl. Acad. Sci. 114, 9134-9139. (2017). Landowner surveys indicate resistance to incentive programs allowing for marsh migration on private property.

12. Barbier, E. B. et al. The value of estuarine and coastal ecosystem services. Ecol. Monogr. 81, 169-193 (2011).

13. Feagin, R. A., Martinez, M. L., Mendoza-Gonzalez, G. \& Costanza, R. Salt marsh zonal migration and ecosystem service change in response to global sea level rise: a case study from an urban region. Ecol. Soc. 15, 14 (2010).

14. Shreve, F., Chrysler, M.A., Blodgett, F.H., \& Besley, F.W. The plant life of Maryland. Special Publication, Volume III, Maryland Weather Service. Baltimore, Maryland: The Johns Hopkins Press (1910).

15. Robichaud, A. \& Begin, Y. The effects of storms and sea level rise on a coastal forest margin in New Brunswick, Eastern Canada. J. Coast. Res. 13, 429-439 (1997).

16. Smith, J. A. The Role of Phragmites australis in Mediating Inland Salt Marsh Migration in a MidAtlantic Estuary. PLoS ONE 8, e65091 (2013). Invasive Phragmites is the dominant species in submerged forests.

17. Raabe, E. A. \& Stumpf, R. P. Expansion of tidal marsh in response to sea-level rise: Gulf Coast of Florida, USA. Estuaries Coast 39, 145-157 (2016).

18. Langston, A.K., Kaplan, D.A. \& Putz, F.E. A casualty of climate change? Loss of freshwater forest islands on Florida's Gulf Coast. Glob. Chang. Biol. 23, 5383-5397 (2017).

19. Schieder, N. W., Walters, D. C. \& Kirwan, M. L. Massive upland to wetland conversion compensated for historical marsh loss in Chesapeake Bay, USA. Estuaries Coast 41, 940-951 (2018). 100,000 acres of marsh migration since 1850 in Chesapeake region. 
20. Schieder, N.W. Reconstructing Coastal Forest Retreat and Marsh Migration Response to Historical Sea Level Rise. MS Thesis, College of William and Mary- Virginia Institute of Marine Science. Williamsburg, VA, 104 pp., doi:10.21220/V5VM9R (2017).

21. Conner, W. H., K. W. Krauss \& T. W. Doyle. Ecology of tidal freshwater forests in coastal deltaic Louisiana and northeastern South Carolina. In Ecology of Tidal Freshwater Forested Wetlands of Southeastern United States. 223-253. (Springer, Dodrecht, 2007).

22. Noe, G. B., Krauss, K. W., Lockaby, B. G., Conner, W. H. \& Hupp, C. R. The effect of increasing salinity and forest mortality on soil nitrogen and phosphorus mineralization in tidal freshwater forested wetlands. Biogeochemistry 114, 225-244 (2013).

23. Fitzgerald, D. M., Fenster, M. S., Argow, B. A. \& Buynevich, I. V. Coastal impacts due to sea-level rise. Annu. Rev. Earth Planet. Sci. 36, 601-47 (2008).

24. Kirwan, M. L. \& J. P. Megonigal, J.P. Tidal wetland stability in the face of human impacts and sealevel rise. Nature 504, 53-60 (2013). Proposes that wetland fate largely depends on how humans respond to sea level rise and influence transgression into adjacent uplands.

25. McKee, K.L., Cahoon, D.R. \& Feller, I.C. Caribbean mangroves adjust to rising sea level through biotic controls on change in soil elevation. Glob. Ecol. Biogeogr. 16, 545-556 (2007).

26. Rodriguez, A. B. et al. Oyster reefs can outpace sea-level rise. Nature Climate Change 4, 493-497 (2014).

27. Sallenger, A.H.S., Doran, K.S. \& Howd, P.A. Hotspot of accelerated sea-level rise on the Atlantic coast of North America. Nat. Clim. Change 2, 884-888 (2012).

28. Craft, C. B. Tidal freshwater forest accretion does not keep pace with sea level rise. Glob. Change. Biol. 18, 3615-3623 (2012).

29. Ross, M.S., O'Brien, J.J. \& Sternberg, S.L. Sea-level rise and the reduction in pine forests in the Florida Keys. Ecol. Appl. 4, 144-156 (1994).

30. Williams, K. et al. Sea-level rise and coastal forest retreat on the west coast of Florida, USA Ecology 80, 2045-2063 (1999). Recruit failure precedes mortality of adult trees in retreating coastal forests.

31. Ma, Z. J. et al. Rethinking China's new great wall. Science 346, 912-914 (2014).

32. Brinson, M. M., Christian, R. R. \& Blum, L. K. Multiple states in the sea-level induced transition from terrestrial forest to estuary. Estuaries 18, 648-659 (1995). Changes in marsh size determined by the balance between erosion and forest retreat.

33. Wasson, K., Woolfolk, A. \& Fresquez, C. Ecotones as indicators of changing environmental conditions: Rapid migration of salt marsh-upland boundaries. Estuaries Coast 36, 654-664 (2013).

34. Field, C. R., Gjerdrum, C. \& Elphick, C. S. Forest resistance to sea-level rise prevents landward migration of tidal marsh. Biol. Conserv. 201, 363-369 (2016).

35. Hussein, A. H. Modeling of sea-level rise and deforestation in submerging coastal ultisols of Chesapeake Bay. Soil Sci. Soc. of Amer. Journ. 73, 185-196 (2009).

36. Clark, J. S. Coastal forest tree populations in a changing environment, Southeastern Long Island, New York. Ecol. Monogr. 56, 259-277 (1986).

37. Anisfeld, S. C., Cooper, K. R. \& Kemp, A. C. Upslope development of a tidal marsh as a function of upland land use. Glob. Chang. Biol. 23, 755-766. (2017). Marsh vegetation develops rapidly in submerging suburban lawns and is not inhibited by mowing.

38. Bhattachan, A. et al. Sea level rise impacts on rural coastal social-ecological systems and the implications for decision making. Environ. Sci. Policy 90, 122-134 (2018).

39. Ardón, M., Morse, J. L., Colman, B. P. and Bernhardt, E. S. Drought-induced saltwater incursion leads to increased wetland nitrogen export. Glob. Chang. Biol. 19, 2976-2985 (2013).

40. Da Lio, C., Carol, E., Kruse, E., Teatini, P. \& Tosi, L. Saltwater contamination in the managed low-lying farmland of the Venice coast, Italy: an assessment of vulnerability. Sci. Total Environ. 533, 356-369 (2015). 
41. Vanderplank, S., Ezcurra, E., Delgadillo, J., Felger, R. \& McDade, L. A. Conservation challenges in a threatened hotspot: agriculture and plant biodiversity losses in Baja California, Mexico. Biodivers. Conserv. 23, 2173-2182 (2014).

42. Khanom, T. Effect of salinity on food security in the context of interior coast of Bangladesh. Ocean \& Coast. Manage. 130, 205-212 (2016).

43. Kang, L., Ma, L. \& Liu, Y. Evaluation of farmland losses from sea level rise and storm surges in the Pearl River Delta region under global climate change. J. Geogr. Sci. 26, 439-456 (2016).

44. Wassmann, R., Hien, N. X., Hoanh, C. T. \& Tuong, T. P. Sea level rise affecting the Vietnamese Mekong Delta: water elevation in the flood season and implications for rice production. Clim. Chang. 66, 89-107 (2004).

45. Teobaldelli, M., Mencuccini, M. \& Piussi, P. Water table salinity, rainfall and water use by umbrella pine trees (Pinus pinea L.). Plant Ecol. 171, 23-33 (2004).

46. Begin, Y. The effects of shoreline transgression on woody plants, Upper St. Lawrence Estuary, Québec. J. Coast. Res. 815-827 (1990).

47. Fernandes, A., Rollinson, C.R., Kearney, W.S., Dietze, M.C. \& Fagherazzi, S. Declining radial growth response of coastal forests to hurricanes and nor'easters. J. Geophys. Res. Biogeosci. 123, 82-849 (2018)

48. Kirwan, M. L., Kirwan, J. L. \& Copenheaver, C. A. Dynamics of an estuarine forest and its response to rising sea level. J. Coast. Res. 23, 457-463 (2007).

49. Tate, A. S., \& Battaglia, L. L. Community disassembly and reassembly following experimental storm surge and wrack application. J. Veg. Sci. 24, 46-57 (2013).

50. Gedan, K. B., \& Fernández-Pascual, E. Salt marsh migration into salinized agricultural fields: a novel assembly of plant communities. In review.

51. Pezeshki, S. R., DeLaune, R. D. \& Patrick Jr., W. H. Flooding and saltwater intrusion: potential effects on survival and productivity of wetland forests along the US Gulf Coast. For. Ecol. Manage. 33:287301 (1990).

52. Barrett-Lennard, E. G. The interaction between waterlogging and salinity in higher plants: causes, consequences and implications. Plant Soil 253, 35-54 (2003).

53. Conner, W. H. The effect of salinity and waterlogging on growth and survival of baldcypress and Chinese tallow seedlings. J. Coast. Res. 1045-1049 (1994).

54. Desantis, L. R., Bhotika, S., Williams, K. \& Putz, F. E. Sea-level rise and drought interactions accelerate forest decline on the Gulf Coast of Florida, USA. Glob. Chang. Biol. 13, 2349-2360 (2007).

55. Hosseini, M. K., Powell, A. A. \& Bingham, I. J. Comparison of the seed germination and early seedling growth of soybean in saline conditions. Seed Sci. Res. 12, 165-172 (2002).

56. Ashraf, M., \& Waheed, A. Screening of local/exotic accessions of lentil (Lens culinaris Medic.) for salt tolerance at two growth stages. Plant Soil 128, 167-176 (1990).

57. Tolliver, K.S., Malxin, D.W., \& Young, D.R., Freshwater and saltwater flooding response for woody species common to barrier island swales. Wetlands 17, 10-18 (1997).

58. Katerji, N., Mastrorilli, M., Lahmer, F. Z. \& Oweis, T. Emergence rate as a potential indicator of crop salt-tolerance. Eur. J. Agron. 38, 1-9 (2012).

59. Tanji, K. K. \& Kielen, N. C. Agricultural drainage water management in arid and semi-arid areas. FAO (2002).

60. Chapman, E. L., Chambers, J. Q., Ribbeck, K. F., Baker, D. B., Tobler, M. A., Zeng, H. \& White, D. A. Hurricane Katrina impacts on forest trees of Louisiana's Pearl River basin. For. Ecol. Manage. 256, 883-889 (2008).

61. Middleton, B. A. Differences in impacts of Hurricane Sandy on freshwater swamps on the Delmarva Peninsula, Mid-Atlantic Coast, USA. Ecol. Eng. 87, 62-70 (2016). 
62. Yu, X., Yang, J., Graf, T., Koneshloo, M., O’Neal, M. A. \& Michael, H. A. Impact of topography on groundwater salinization due to ocean surge inundation. Water Resour. Res. 52, 5794-5812 (2016).

63. Elsayed, S. M. \& Oumeraci, H. Modelling and mitigation of storm-induced saltwater intrusion: Improvement of the resilience of coastal aquifers against marine floods by subsurface drainage. Environ. Model. Soft. 100, 252-277 (2018).

64. Poulter, B., Goodall, J. L. \& Halpin, P. N. Applications of network analysis for adaptive management of artificial drainage systems in landscapes vulnerable to sea level rise. J. Hydrol. 357, 207-217 (2008).

65. Craft, C. et al. Forecasting the effects of accelerated sea-level rise on tidal marsh ecosystem services. Front. Ecol. Environ. 7, 73-78 (2009).

66. Jordan, T. E., and Weller, D. E. Human contributions to terrestrial nitrogen flux. BioScience 46, 655664 (1996).

67. Tully, K., Weissman, D., Wyner, W. J., Miller, J. \& Jordan, T. E. Soils in transition: saltwater intrusion alters soil chemistry in agricultural fields. Biogeochemistry 142, 339-356 (2019).

68. Smith, V. H., \& Schindler, D. W. Eutrophication science: where do we go from here? Trends Ecol. Evol. 24, 201-207 (2009).

69. Cook, C. E., McCluskey, A. M. \& Chambers, R. M. Impacts of invasive Phragmites australis on diamondback terrapin nesting in Chesapeake Bay. Estuaries Coast. 41, 966-973 (2018).

70. Field, C.R. et al. High-resolution tide projections reveal extinction threshold in response to sea-level rise. Glob. Chang. Biol. 23, 2058-2070 (2017)

71. Spector, T. \& Putz, F. E. Biomechanical plasticity facilitates invasion of maritime forests in the southern USA by Brazilian pepper (Schinus terebinthifolius). Biol. Invasions 8, 255-260 (2006).

72. Kirwan, M. L., Temmerman, S., Skeehan, E. E., Guntenspergen, G. R. \& Fagherazzi, S. Overestimation of marsh vulnerability to sea level rise. Nat. Clim. Chang. 6, 253-260 (2016).

73. Lovelock, C. E. et al. The vulnerability of Indo-Pacific mangrove forests to sea-level rise. Nature 526, 559-563 (2015).

74. Crosby, S.C., Sax, D F., Palmer, M. E., Booth, H. S., Deegan, L. A., Berness, M. D. \& Leslie, H. M. Salt marsh persistence is threatened by predicted sea-level rise. Estuar. Coast. Shelf Sci. 181, 93-99 (2016).

75. Dahl, T. E. \& Stedman, S. M. Status and trends of wetlands in the coastal watersheds of the Conterminous United States 2004 to 2009. U.S. Department of the Interior, Fish and Wildlife Serve \& National Oceanic and Atmospheric Administration, National Marine Fisheries Service, 107 pgs. (2013)

76. Kirwan, M. L., Walters, D. C., Reay, W. G. \& Carr, J. A. Sea level driven marsh expansion in a coupled model of marsh erosion and migration. Geophys. Res. Lett. 43, 4366-4373 (2016).

77. Enwright, N.M., Griffith, K.T. \& Osland, M.J. Barriers to and opportunities for landward migration of coastal wetlands with sea-level rise. Front. Ecol. Evol. 14, 307-316. (2016). Large areas of land are available for migration on the Gulf Coast, but with large geographic variability due to anthropogenic and topographic barriers.

78. Schile, L. M. et al. Modeling tidal marsh distribution with sea-level rise: Evaluating the role of vegetation, sediment, and upland habitat in marsh resiliency. PLOS ONE 9, e88760 (2014).

79. Cadol, D., Elmore, A., Guinn, S., Engelhardt, K. A. M. \& Sanders, G. Modeled tradeoffs between developed land protection and tidal habitat maintenance during rising sea levels. PLOS ONE 11 e0164875 (2016).

80. Torio, D. D. \& Chmura, G. L. Assessing coastal squeeze of tidal wetlands. J. Coast. Res. 29, 1049-1061 (2013)

81. Thorne, K. et al. US Pacific coastal wetland resilience and vulnerability to sea-level rise. Sci. Adv. 4, eaao3270 (2018). 
82. Borchert, S.M., Osland, M.J., Enwright, N.M. \& Griffith, K.T. Coastal wetland adaption to sea level rise: quantifying potential for landward migration and coastal squeeze. J. Appl. Ecol. 1-12 (2018).

83. Schuerch, M. et al. Future response of global coastal wetlands to sea level rise. Nature 561, 231234 (2018). Marsh loss is not inevitable but depends on anthropogenic barriers to marsh migration.

84. Temmerman, S., Meire, P., Bouma, T. J., Herman, P. M., Ysebaert, T., \& De Vriend, H. J. Ecosystembased coastal defense in the face of global change. Nature 504, 79-83 (2013).

85. Mitchell, M., Herman, J., Bilkovic, D. M. \& Hershner, C. Marsh persistence under sea-level rise is controlled by multiple, geologically variable stressors. Ecosyst. Health Sustainability 3, 10 (2017).

86. Titus, J. G. et al. State and local governments plan for development of most land vulnerable to rising sea level along the US Atlantic coast. Environ. Res. Lett. 4, 044008, 1-7 (2009).

87. Gray, A., Simenstad, C. A., Bottom, D. L. \& Cornwell, T. J. Contrasting functional performance of juvenile salmon habitat in recovering wetlands of the Salmon River estuary, Oregon, USA. Restor. Ecol. 10, 514-526 (2002).

88. Williams, P. B. \& Orr, M. K. Physical evolution of restored breached levee salt marshes in the San Francisco Bay estuary. Restor. Ecol. 10, 527-542 (2002).

89. Smith, J. A., Hafner, S. F., \& Niles, L. J. The impact of past management practices on tidal marsh resilience to sea level rise in the Delaware Estuary. Ocean Coast. Manage. 149, 33-41 (2017).

90. Temmerman, S. \& Kirwan, M. L. Building land with a rising sea. Science 349, 588-589 (2015).

91. Syvitski, J.P. et al. Sinking deltas due to human activities. Nat. Geosci. 2, 681-686 (2009).

92. Hinkel, J. et al. Coastal flood damage and adaptation costs under 21st century sea-level rise. Proc. Natl. Acad. Sci. 111, 3292-3297 (2014).

93. Doyle, T. W. et al. Predicting the retreat and migration of tidal forests along the northern Gulf of Mexico under sea-level rise, For. Ecol. Manage. 259, 770-777 (2010).

94. Wong, P. P. et al. Coastal Systems and Low-Lying Areas. In Climate Change 2014: Impacts, Adaptation, and Vulnerability. Part A: Global and Sectoral Aspects. Contribution of Working Group II to the Fifth Assessment Report of the Intergovernmental Panel on Climate Change. (eds Field, C.B et al.) Cambridge University Press, New York, NY, 2014).

95. Renaud, F. G. et al. Tipping from the Holocene to the Anthropocene: how threatened are major world deltas? Curr. Opin. Environ. Sustain. 5, 644-654 (2013).

96. Tessler, Z. D., Vörösmarty, C. J., Grossberg, M., Gladkova, I., Aizenman, H., Syvitski, J. P. M. \& Foufoula-Georgiou, E. Profiling risk and sustainability in coastal deltas of the world. Science 349, 638-643 (2015).

97. Schmidt, J. P., Moore, R. \& Alber, M. Integrating ecosystem services and local government finances into land use planning: a case study from coastal Georgia. Landsc. Urban Plan. 122, 56-67 (2014).

98. Voutsina, N., Seliskar, D. M. \& Gallagher, J. L. The facilitative role of Kosteletzkya pentacarpos in transitioning coastal agricultural land to wetland during sea level rise. Estuaries Coast 38, 35-44 (2015).

99. Neal, W. J., Pilkey, O. H., Cooper, J. A. G. \& Long, N. J. Why coastal regulations fail. Ocean Coast. Manage. 156, 21-34 (2018).

100.Calil, J., Beck, M. W., Gleason, M., Merrifield, M., Klausmeyer, K. \& Newkirk, S. Aligning natural resource conservation and flood hazard mitigation in California. PLOS ONE 10, e0132651 (2015).

Explores conservation and buyout programs for flood prone land. 


\section{Acknowledgements}

This work was supported by the U.S. National Science Foundation (Coastal SEES \#1426981; LTER \#1237733; CAREER \#1654374), and the USDA Agricultural and Food Research Initiative Competitive Program (\#2018-68002-27915). SouthWings provided a flight that helped motivate the work.

\section{Figures}

Figure 1. Geographic distribution of sea-level driven land conversion in North America. Clockwise from top left: Red spruce ghost forest and buried stumps, New Brunswick, Canada; Atlantic white cedar ghost forest in New Jersey; Salt damaged agricultural field in Virginia, where white and gray areas represent bare ground, and yellow-red colors represent stressed crops; Palm tree ghost forest in Florida. Photo sources: D. Johnson, K. Able, Google Earth, and A. Langston.

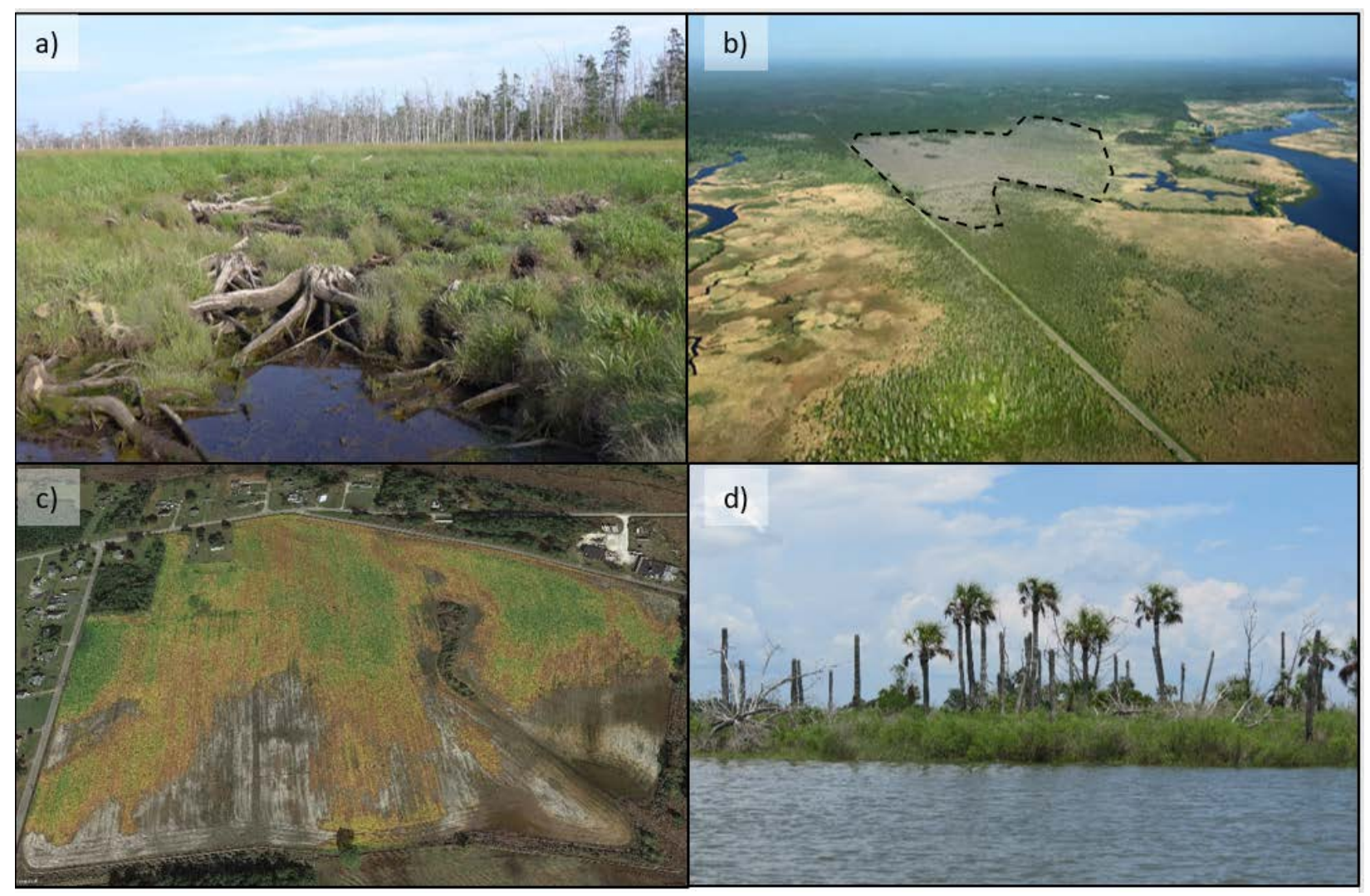


Figure 2. Accelerating forest retreat rates. Lateral forest retreat rates for 5 U.S. mid-Atlantic sites, where gold bars represent late-Holocene rates (pre-1875 CE) inferred from sediment cores and historical maps, and green bars represent modern rates (post-1875 CE) inferred from historical maps and aerial photographs. 1875 CE was chosen to approximate the initiation of accelerated sea level rise on the Atlantic coast ${ }^{1}$. Modern forest retreat rates are 2-14 $\mathrm{X}$ higher than late-Holocene rates, and generally increase through time. Source: Ref [20].

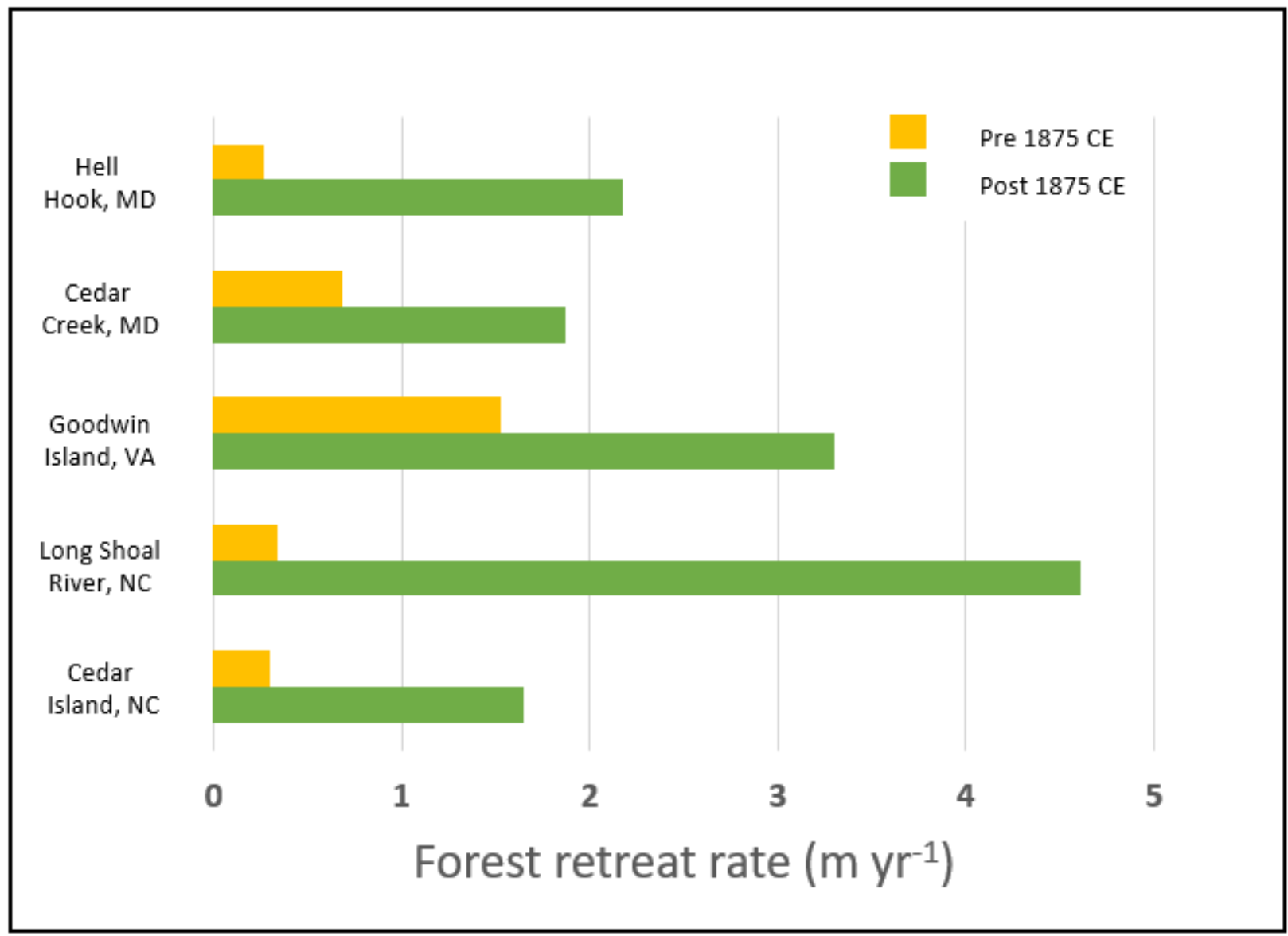


Figure 3. Stages of ghost forest creation. Photos show forest to marsh conversion in the Chesapeake Bay region (Maryland, USA), characterized by (a) death of tree saplings, (b) opening of canopy and invasion of Phragmites and shrubs, (c) adult tree death and conversion to marsh, indicated by stumps in foreground and ghost forest in background. Photo sources: K. Gedan, M. Sall, and L. Schepers.

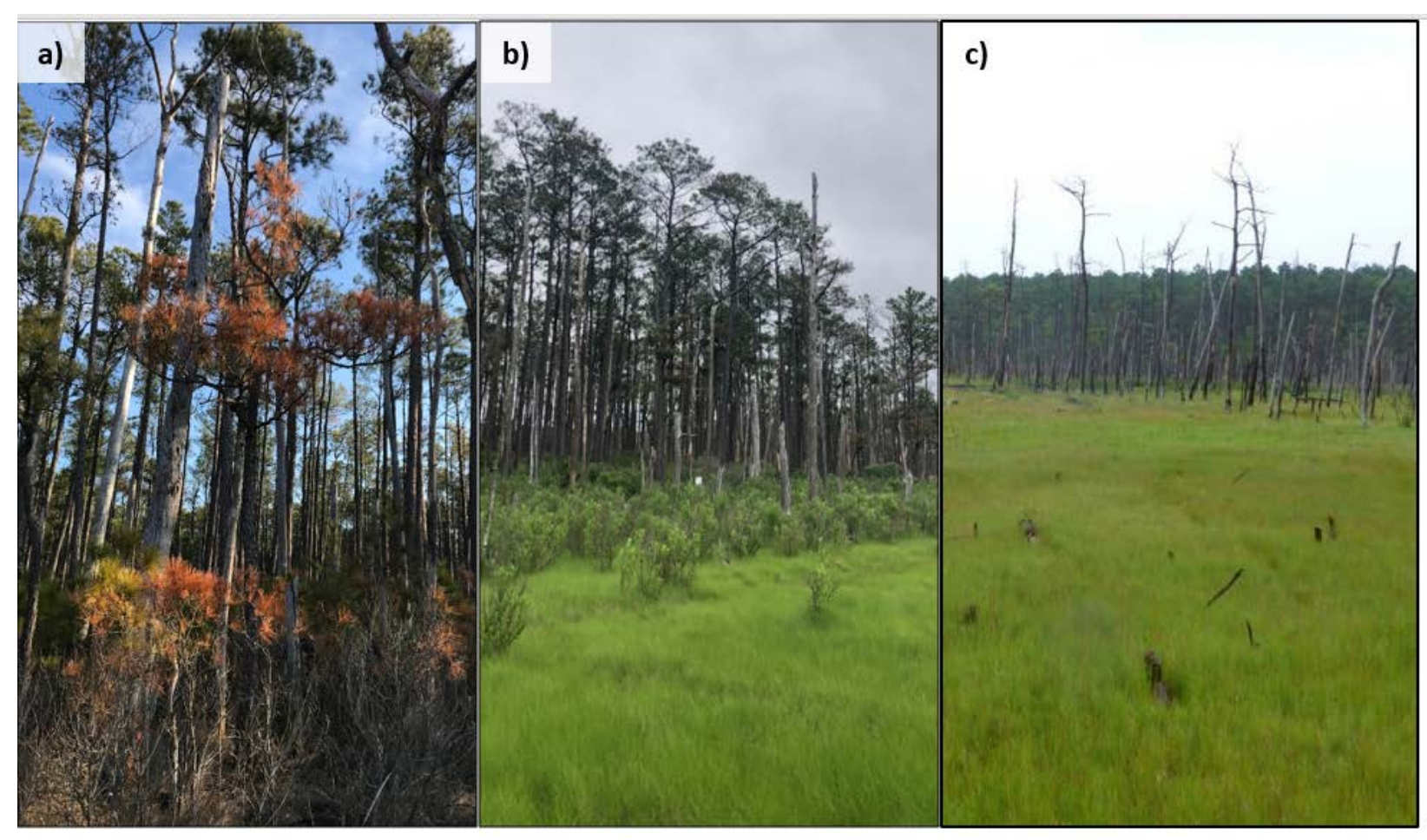


Figure 4. Effect of topographic slope and human impacts on marsh size. a) Model simulations showing change in marsh width (dMW/dt) for different rates of sea level rise (SLR) and slopes of adjacent land (colored lines). For gently sloping, natural coasts, marshes expand with increasing sea level rise rates until a threshold rate of sea level rise is exceeded. Marshes inevitably decline in size when uplands are steep or protected by anthropogenic barriers (black line represents case with no migration). Source: Ref [76]. b) steep uplands prevent landward marsh migration and favor small and/or shrinking marshes (Bay of Fundy, Nova Scotia). c) Gently sloping uplands facilitate landward marsh migration and favor large and/or expanding marshes (Chesapeake Bay, MD). Photo sources: M. Kirwan and L. Schepers.
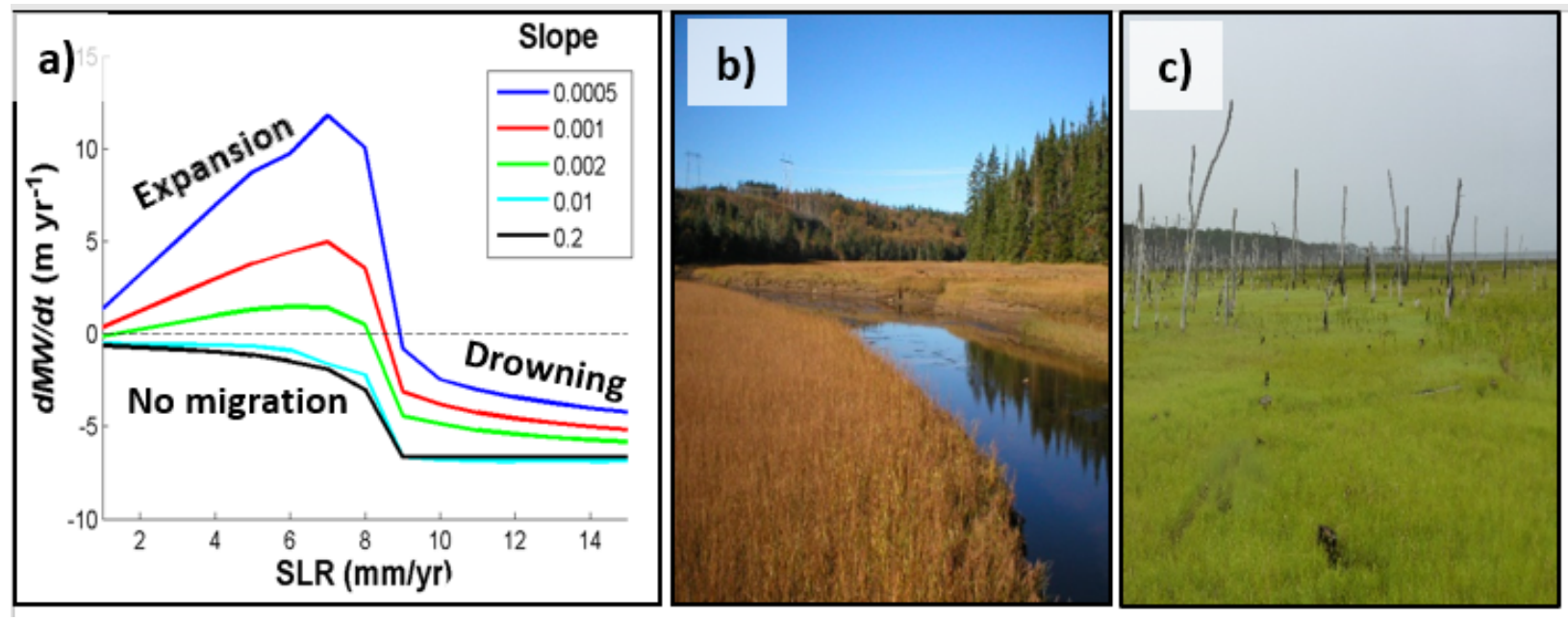

Figure 5. Effect of flood defense strategy and land conversion on wetland size. a) Nature-based engineering to create marsh in front of leveed agricultural fields in the Wash Estuary, U.K. The levee was intentionally breached in 2002, marsh vegetated colonized naturally, and now protects the more inland levee. Photo source: U.K. Environment Agency. b) Modeled global wetland area for the IPCC RCP 8.5 sealevel rise scenario. Colors represent different flood-defense scenarios, where the model assumes no landward wetland migration where the projected human population in the 100 year floodplain exceeds 5-20 people $\mathrm{km}^{-2}$ (red, reflecting business as usual), 20-150 people $\mathrm{km}^{-2}$ (pink), and 150-300 people $\mathrm{km}^{-2}$ (yellow, reflecting extensive nature-based engineering). Source: Ref [83].
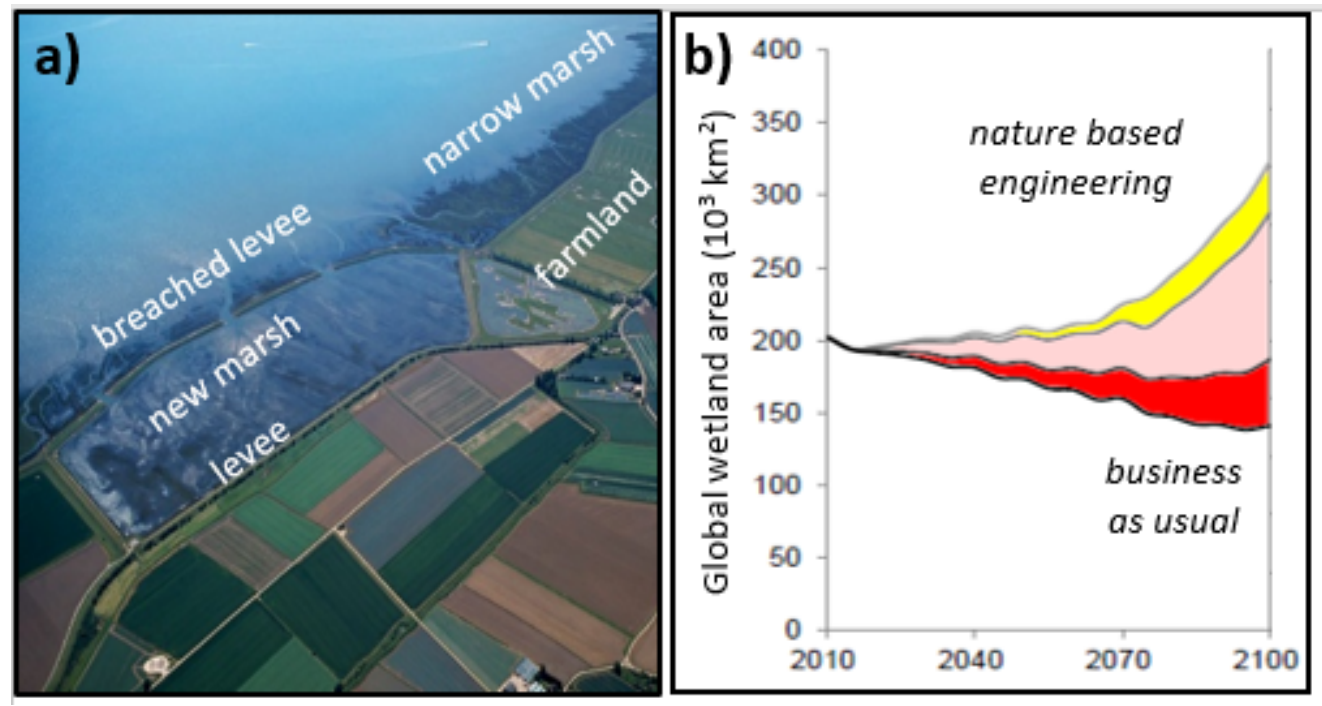
Figure 6. Land conversion in the face of human barriers. a) Projected urban barriers and opportunities for wetland migration for U.S. Gulf Coast estuaries (Borchert et al., 2018). Opportunities for wetland migration are an order of magnitude greater than urban barriers to migration in each estuary, and potential wetland migration increases with increasing sea level rise scenario (top to bottom). b) Preferences of 1002 landowners regarding conservation easements to allow marsh migration in the Northeastern U.S. Responses are strongly unlikely (SU), unlikely (U), neutral (N), likely (L), and strongly likely (SL). Source: Ref [11].
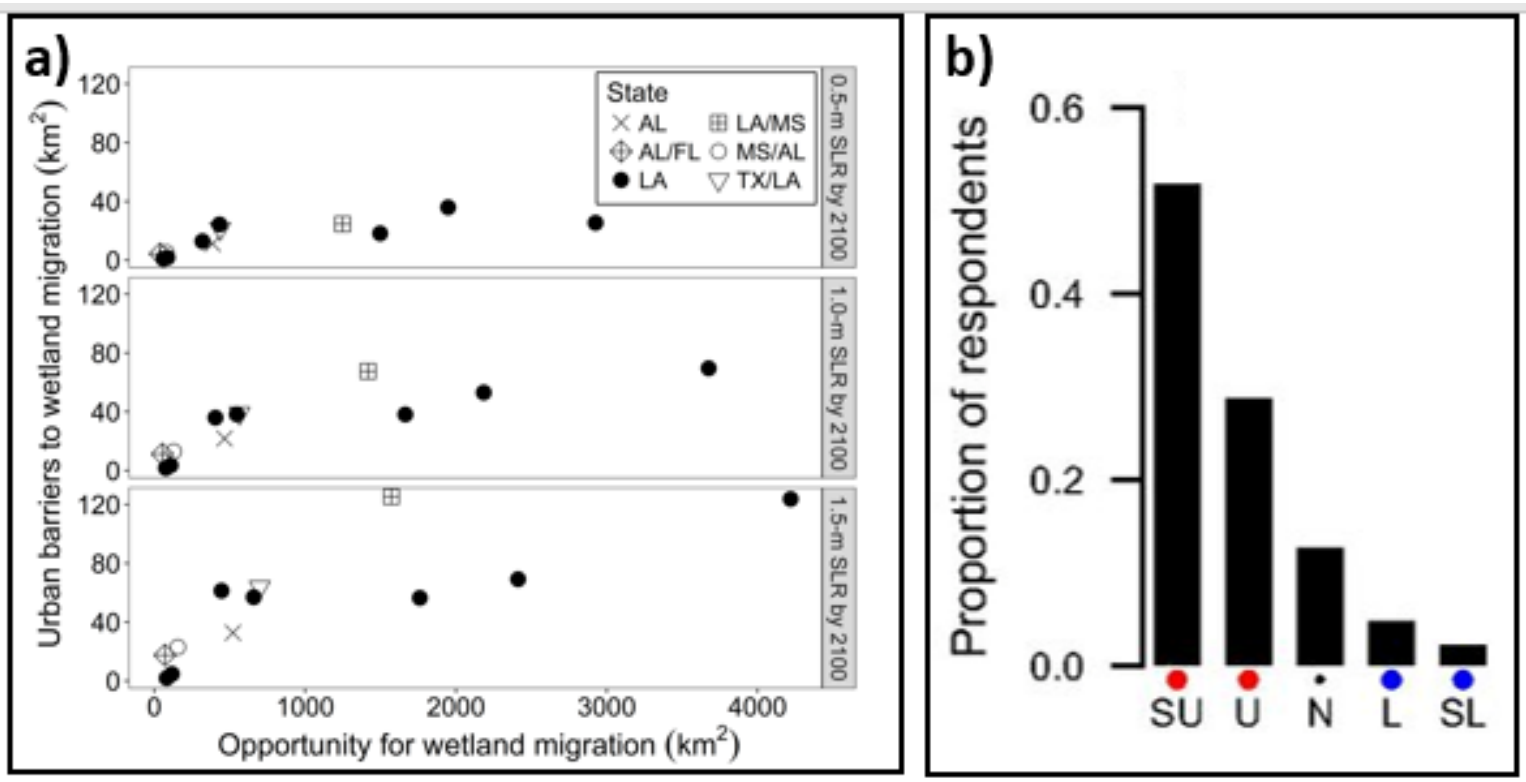